\title{
SYNCHRONIZATION OF ENGLISH STUDENTS' WORKSHEET (LKS) TO THE CURRICULUM
}

\author{
Neneng Heni Nurhidayah, Farouk Imam Arrasyid. \\ IAIN Syekh Nurjati Cirebon \\ Email: nenengheni18@gmail.com; faroukarrasyid@gmail.com
}

\begin{abstract}
This analysis is intended to uncover the synchronization between the students' worksheet for vocational high school to the School Based Curriculum. This research explores the profile of the English students' worksheet; evaluate the synchronization between the English students' worksheet's content and assessment to the learning objective in curriculum. This research utilizes qualitative research design, particularly in the form of a descriptive-evaluative content analysis. The data collection technique is in non-participant analysis study. The primary data is one printed students' worksheet entitled "BAHASA INGGRIS Untuk SMK TEKNIK" published by MARGA MITRA and is used in SMK Al-Hidayah Cirebon. The data are analyzed by using textbook evaluation checklists which are represented into percentage and described into paragraph description as the result. The result of the research shows that the analyzed students' worksheet obtains over a third of poor items, nearly two third of good items, and only a small portion of excellent. It means that this students' worksheet is mostly categorized good in the term of general evaluation. However, fact found that some contents and assessments in this students' worksheet are out of the guidance in the syllabus. It is clear that it contains roughly a quarter of not synchronous assessment in speaking, nearly a third in reading, and nearly two third in writing. It indicates that the references and the guidance of the students' worksheet are questionable and untrustworthy.
\end{abstract}

Keywords: Students' Worksheet, Synchronization, Curriculum, Syllabus, Learning Objective.

\section{BACKGROUND}

All language learning needs books and worksheets in the process of learning, so does English learning. The existence of books and worksheets are inseparable from English learning process to provide the material and assessment in the learning process. These books are considered important for teacher and student to understand the teaching material. The needs of material indicate that the selection of book cannot be done carelessly. There are factors as consideration, those are quality and the synchronization of the content of the book and assessment to the applied curriculum. Therefore, the users of the books must wisely choose, select, and determine the most appropriate book to be used in learning process.

Textbooks and the other supplements are chosen as source of learning and to provide the material because those material and assessment providers are suitable with the standardized curriculum. One of the supplements of the textbook that used in English teaching learning process in Indonesia is Lembar Kerja Siswa (LKS)-here and then students' worksheet - . The role of students' worksheet is as important as main course book in learning process. In some schools, teachers even use students' worksheets as primary learning source. The students' worksheet usually contains brief material and some assignments to check students' understanding of certain material. Anyhow, it is assumed that although students' worksheets have their meaningful role, 
they are not always well designed and the contents are not always synchronous to the curriculum and correspond with the objective of the teaching program and students' needs.

Therefore, the researcher evaluates the quality of the technical vocational students' worksheet by using some checklist evaluations adapted from some experts such as Wahab, Lawrence, Bitterlin, Weddel, etc. This research concerns to evaluation of the Student Worksheets' profile, content, and assessments. The analysis provides some evidences to prove the judgements.

\section{Students' Worksheet (LKS)}

Students' worksheet (LKS) is a printed instructional material in the form of a sheet contains tasks and instructions, the steps to complete the task. Students' worksheet can be a guide for the development of cognitive training and guidance for the development of all aspects of learning in the form of guide experiments and demonstration (Trianto: 2007). Students' worksheet is usually in the form of instructions, step for completing and sheet activities that states the clear basic competence that will be achieved (Depdiknas: 2004).

Students' worksheet is also equipped with other books or other reference materials related to its work (Madjid: 2007). According to the definition above, the students' worksheet is sheet contains the tasks of teachers to students that are arranged to the basic competencies and learning objectives to be achieved. In conclusion, Students' worksheet is a working guide students to facilitate students in the implementation of learning activities.

\section{Assessment}

Assessment is the application of variety ways and variety assessment tools to obtain information about the extent to which the results of student learning or achievement of learners' competence (capability). Assessment answers the questions about how well the results or the learning achievement of the students. The value of assessment can be qualitative (narrative statement in words) and a quantitative value (numeric). Assessment related to the search process or determining the quantitative value.

Assessment as an evaluation tool in the School Based Curriculum (KTSP), at the level of the syllabus, have basic competencies that are focused on three areas or categories realm (domain), namely cognitive (things that should be known and understood by students), psychomotor (things performed by students after having knowledge) and affective (attitude after the students' learning process is given).

Assessment of learning is also a process or an attempt at a formal gathering information related to the key variables of learning as an ingredient in decision making by the teacher to improve processes and student learning outcomes (Po-pham: 1995 in Mulyasa : 2010). Important variables in question at a lack of covering knowledge, understanding, skills and attitudes of students in the lessons learned teachers with different methods and procedures, both formal and informal.

According to Brown (2003), assessment is an ongoing process that encompasses a much wider domain than ability, knowledge, or performance. Whenever a student responds to a question, offers a comment, or tries out a new word or structure, the teacher subconsciously makes an assessment of the student's performance. Brown 
divided language assessment into some basic types and give the designing task of each basic type.

\section{Curriculum}

Neagley and Evans (1967), define the notion of curriculum is all the experience that has been designed by the school. Indonesia kept changing curriculum since the first time it emerged. The first curriculum was developed and implemented in Indonesia in 1975. According to the 1975 curriculum the objective of English teaching in high school was to facilitate the development of advance science, technology, culture, and arts, and to foster international relations. The four language skills: reading, writing, listening, and speaking were taught discretely.

Then, the ministry of education revised the national curriculum became 1984 Curriculum. The teaching method that was adopted in 1984 curriculum was known as the 'Communicative Approach'. In 1994, another curriculum was introduced. In 1994 curriculum, the most important language skill was reading, followed by listening, speaking, and writing. Language skills and language elements were no longer taught separately as in 1984 curriculum.

A competency-based curriculum was adopted in 2004. In the previous curriculum trimester the school calendar was used. In the 2004 curriculum one semester school calendar was introduced. The quality of education was controlled by the government by setting basic competencies and standard competencies. These competencies are measured by a standardized national test at the end of year. Besides, it also emphasizes communication to face the global economy and global education.

In line with the implementation of the Regional Autonomy Law in 2006, the ministry of education promoted school-based management and school-based curriculum. It explains that schools are expected to developed their own curriculum and be independent financially. However, the adaptation of a school based management system only useful for schools in the cities and in the well-developed areas. Schools in the less developed and rural areas suffer a lack of resources because of the significant budget cut from the central government. (Fitriyani, 2013).

In 2013, the government finally decided to try out the new designed curriculum, the 2013 curriculum. Although there are a lot of debates about the lack of preparation and infrastructure, the 2013 curriculum offers many new features in our education system. The 2013 curriculum is IT-based. Ministry of Education and Culture has set up a website to oversee the implementation. The 2013 curriculum is now smoothly implemented along with School Based Curriculum (KTSP)

School Based Curriculum (KTSP) is operational curriculum drafted, developed, and implemented by each educational unit with respect to the standards of competence and basic competences developed National Education Standards Agency (BSNP). Preparation of KTSP conducted by educational units with attention and based on standards of competence and basic competence developed by the National Education Standards Agency (BSNP).

School Based Curriculum (KTSP) has standard of competence, basic competence, and indicators. These competences can measure students' abilities, skills and attitudes. So that, it can be used to assess the achievement of learning outcomes and is also used as a benchmark the extent to which the students' mastery of a particular subject. Therefore, those aspects are very important to achieve the learning objectives.

\section{Textbook Evaluation}


In the selection of a textbook, including students' worksheet, it is very essential to conduct an evaluation to make sure that students' worksheet is suitable. Through the evaluation of a textbook, teachers know the content of the book, its strengths and weaknesses which will facilitate them to adapt it to suit the course aims, learners' needs and teachers' beliefs (Anjaneyulu, 2014).

There are some consideration in synchronizing material to the curriculum, those are; 1) students' potential, relevance to the culture, 2) level of students' development of physical, intellectual, emotional, social, and spiritual, 3) usefulness of the science, 4)structure of knowledge, 5) actuality, the depth, the breadth of learning materials, 6) relevance to the needs and demands of students' environment, 7) in accordance to the allocation of the available time, and 8) formulate learning activities.

\section{METHOD}

There are two variables that are analyzed in this research. The first variable as a free variable is students' worksheet. While the second variable as a bound variable is the curriculum. Therefore, to analyze those variables this research uses qualitative research, particularly in the form of a descriptive content-analysis. Ary et al, in Kirana (2010) states that descriptive research is designed to obtain information concerning the current status of phenomena. In this research, the phenomenon was about the evaluation of English students' worksheet entitled "BAHASA INGGRIS Untuk SMK TEKNIK" published by MARGA MITRA and is used in SMK Al-Hidayah Cirebon. This research was designed to evaluate students' worksheet and describe the result of the evaluation.

The source of data that is used in this research is one printed students' worksheet containing 64 pages. The data is collected in the form of checklist. This research uses textbook checklist evaluation from some experts including Wahab, Lawrence, Bitterlin, Weddel, etc. The data that is analyzed are the profile, content and assessment. The scoring involves personal evaluation in three categories; excellent, good, and poor. While the synchronization evaluation done by comparing table containing the content, and assessments of the students' worksheet and the learning objective in the syllabus. The categories of synchronization are "Yes" and "No".

To sum up the evaluation, the researcher concludes the result of the analysis in the form of percentage. It is completed by dividing the number of criteria already fulfilled by the students' worksheet with the total number of the evaluation criteria in the term of profile and multiplied by $100 \%$. This method is also applied to the synchronization. The synchronization is revealed by dividing the number of synchronous or not synchronous content with the total number of content and multiplied by $100 \%$. Both percentage is illustrated in the pie chart. Last but not least, the researcher interpreted the description as the result of the research.

\section{FINDINGS}

The analysis of the profile relates to the quality of the general appearance and feature of the students' worksheet. The involved items in the profile are cover table of content, bibliography, visual, appropriateness of title, review and exercise, logic organization, consistency in using heading. clarity of direction aids, layout, quality of paper, picture, glossary, mistake and interesting appearance. Those items are considered important in students' worksheet and must have the good or even excellent quality.

First item is the table of content. Actually, the table of content in the students' worksheet is complete. It shows the three-unit material, equipped by the page number of 
each unit. It also shows the page number of the tests, including Competence Test (test after finishing every unit), Mid Semester Test (after finishing two units), and Semester Test (after finishing three units). The table of content is detail as well. It provides the list of core material in each unit. Unfortunately, it doesn't provide the language skill material and exercise page number in the list.

Recently, there is a table content which contains the learning objective in every unit or lesson. That is the table of content which fulfill the criteria of complete and detail. Therefore, to accomplish the criteria, the learning objective in every unit should be added to the table of content in this students' worksheet. Besides, the table of content should include page number of language skill and page number of assessment. This effort is done in order to the users (teacher and students) can see the brief objective and easier to look for certain task from the table of content.

Second point is the visuals and graphics. The quality of visuals and graphics depends on the design and printing. The visuals and graphics presented in the students' worksheet are merely black and white and not attractive. However, they are clear, well produced, and varied. The visuals and graphics are appropriate for adults. It supports andragogy learning.

Besides, they are culturally sensitive. None of the visuals and graphics display stereotypes, prejudices, gender gap, or anything that is disrespectful to any culture. The quality of visuals and graphics depends on the design and printing. The design is good enough but it will be better if the printing used is the color printing, not the black and white one to make it more attractive.

The third item is the appropriateness of title and heading. The title and heading are appropriate but not interesting. Here are the descriptions of every title and heading. It is begun by the first title "What a Busy Day". This title is appropriate because it covers the material in first unit about business conversation, hobby, and present perfect tense. The second title "With Whom am I talking to?" is appropriate because it covers the material about job description, job interview, and handling conversation on the phone. The third title "What is Your Plan?" is also appropriate because it covers the material about plan and experience, personal letter, simple past tense, and present continuous tense.

Then these are the description of heading. "Learning Motivation" is a section to prepare students' scheme before entering the learning process by giving questions and insights regarding related materials and gives a brief material. "Summary of Material" is heading of main materials. One summary consists of two main material. "Interaction" is the sharing task regarding the material. Then it presents four language skills. The sequence is "Listening", "Speaking", Reading", and "Writing". There are four until six tasks in every language skill; "TASK 1", "TASK 2', etc. After that, it provides additional tasks in "Individual Activity" (personal task), "Group Activity" (task for peer or group of four), and "Exercise" (optional number of students).

In the last pages, the students' worksheet usually provides the "Application of Character Values", it is the character building values that are taken from every unit. "Academic Reflection" is the brief summary and reflection questions regarding the unit that has been learned. "Glossary" is the list of some vocabularies that has been learned in the unit. "Competence Test" is the integrated language skill test after finishing one unit. "Attitude Scale" is the rubric to check students' attitude toward daily life event accompanied by logical reasons. "Remediation" is the exercise for students who achieve Competence Test's score less than average. While "Enrichment" is the exercise for 
students who achieve Competence Test's score more than average. "Portfolio" is an instruction to do activity and write a report based on that activity.

There are some headings that are only appear in certain unit. "Encyclopedia" is the column of additional knowledge and tips to enrich students' understanding related to the material. "Problem Solving" is a real event that is adapted from mass media to be discussed and analyzed due to find the solution. "Grammar Focus" is the column provides grammar lesson. They only appear in Unit 2. "Mid Semester Test" is the integrated test after finishing 2 unit, it appears in Unit 2. "Semester Test" is the integrated test after finishing 3 unit, it appears in Unit 3.

The title of the unit in the students' worksheet is appropriate and interesting but the title of heading (include assessment of language skill) should be changed with more interesting one. For example, instead of using "Listening" for listening language skills, it can use "Let's Listen". The other option is to integrate two skills into one heading, the receptive and the productive one. For example, listening and speaking in one interesting heading will be "Let's Listen and Speak".

The next point is review and exercise. The review section here is available in the column "Application of Character Values", "Academic Reflection" and "Attitude Scale". "Application of Character Values" reviews the material that has been learned while implementing the character building values related to the material. This value will beneficial in students" daily and business life. While "Academic Reflection" is reviewed by giving brief summary of the material and questions whether students have understood the whole material or not. If students have understood, they can learn the next unit. If they have not understood, they should discuss it with teachers and friend.

The "Attitude Scale" section presents review of the material by giving some issues in social life that is related to it. Students' are expected to determine their attitude to those social issues accompanied by logical and responsible reason. The review sections in the form of academic reflection must be developed and extended. Interesting game to recall students' memory about previous material can be added.

While the exercise is rich, it presents in every language skills and activity. However, the exercises are monotone, just listen to the dialogue, read the passage, and practice the conversation then answer the question. The interesting kind of exercise must be provided. The exercise can be cross-word puzzle, game board monopoly, or the simple game like snake and ladder which absolutely has been adapted with English learning content. These kinds of exercises can motivate students' in learning more than the conventional ones.

Next point is the organization of students' worksheet. The students' worksheet in the students' worksheet is organized logically. In the beginning, there is concept map to describe the whole unit. It is continued by Learning Motivation to relive students' scheme and Summary of Material to provide the main learning material. There is always a passage in reading, listening, speaking, and writing. Besides, there are always questions to check students' understanding about the passage.

The students' worksheet is also organized effectively. The receptive language skill is always presented before the productive one. So, students can receive the information in listening and reading before they can reproduce it in speaking and writing. However, it is better if the receptive and productive language skill are integrated become one single package, listening and speaking, reading and writing.

The last point in the profile of students' worksheet is the whole appearance. Generally, if it is seen from the appearance perspective, the students' worksheet doesn't 
look interesting. The appearance looks boring. The visual is not colorful because it uses black and white printing. There are only few pictures so the students' worksheet is not alive. There are no interesting and attractive content that can challenge students in task, exercise or activity in this students' worksheet. They are monotone and not variative. The interesting and fun idea, design, exercise, etc. must be added to make this students worksheet more alive. To sum up the evaluation, below is the chart and description.

\section{Chart 1 Profile}

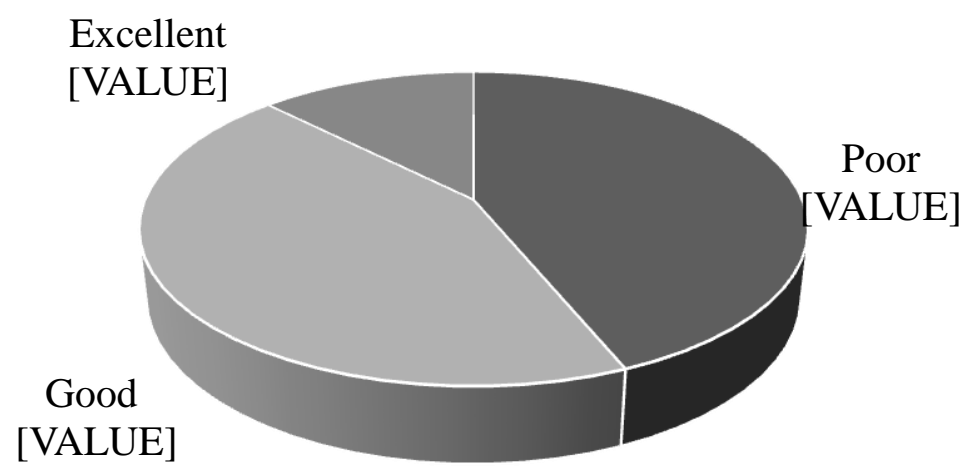

Overall it is clear that the amount of good and poor is same of the entire item. It obtains nearly a half of total category. While the chart shows that the students' worksheet only gains a small fraction of excellent categorized item. It indicates that the students' worksheet's general appearance is well prepared although there are still some aspects that must be developed.

\section{Content}

The analysis of the content relates to the quality of the material and what is contained by the students' worksheet. The items in the content involved the evaluation of up to date material which is suitable to students' need, allows improvisation and selfaccessed learning, inspiring, varied, language used, and thinking skills, audio and CD existence, life skill knowledge, four language skills (listening, speaking, reading, and writing) vocabulary and grammar. Those items are considered important in students' worksheet and must have the good or even excellent quality. Below is the proportion of content evaluation.

\section{Chart 2 Content}

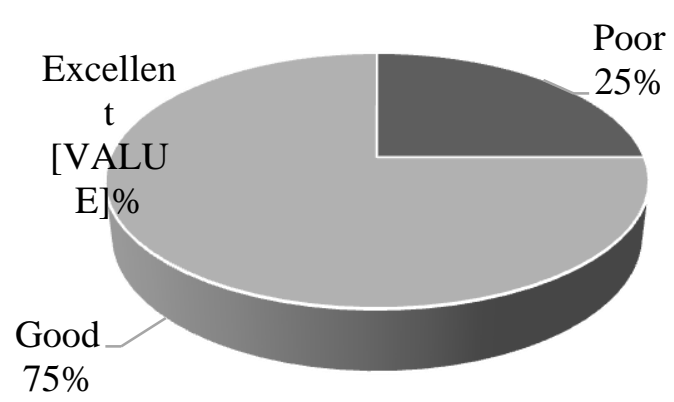

It is the summary of content evaluation. The pie chart illustrates that the students' worksheet obtains precisely three quarters of good in the term of content. The 
poor categorized item obtains only a quarter. While it doesn't obtain any excellent categorized at all. It shows that the quality of students' worksheet's content is merely good. Besides, there are some aspects that must be fixed due to develop the content.

\section{Content Synchronization}

The synchronization between the content in the students' worksheet and the syllabus is very important because syllabus is the guidance to run a learning process. Syllabus contains standard competence, basic competence, material, indicator, assessment, etc. Syllabus is a translation of standard competence and basic competence into material. If the material is not synchronized with the standard competence and basic competence in the syllabus, then it is not acceptable and the guidance is questionable.

This can happen all the time, to all text book, even it happens to well-known brand book and students' worksheet. This is the form of carelessness that is done by both the author and the editor of the book and students' worksheet. Therefore, task of user of this kind of book is to check whether it has been synchronized with the curriculum or not. If it is not, then the book is not appropriate to be used. The other solution is taking only what material is appropriate and leave behind what is not. It is the proportion of content synchronization evaluation.

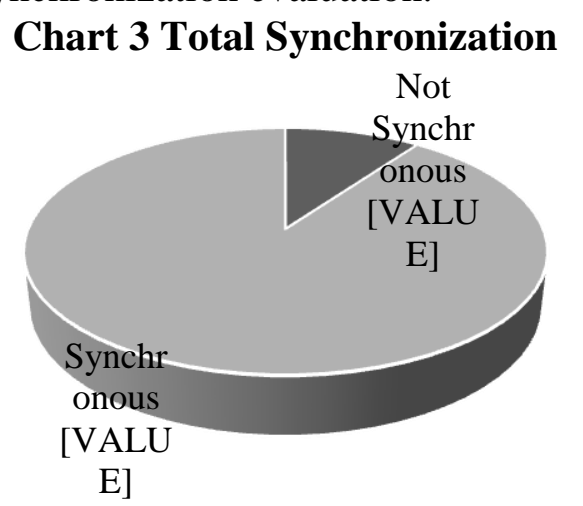

The pie chart illustrates that the students' worksheet contains a small portion of not synchronous content. But the rest it contains synchronous content. The content that is not synchronous is placed in the first unit. The students' worksheet provides the material about present perfect tense which is not stated in the syllabus. It indicates that the quality of students' worksheet's content is hesitated. It is assumed that the writer or the editor did not pay attention on the students of vocational schools' needs in the syllabus.

\section{Assessment}

The analysis of the content relates to the quality of the objective, quality of exercise, language skills and language content assessments. The evaluation of objective is about the evaluation of the starting point of assessment. The assessment is the scorable task to achieve the objective. It explains the description of the objective wholly. It talks about the quality of objective and the relation of objective with aids and methods.

While the evaluation of exercise relates to the quality of assessment in the students' worksheet, the exercises are on the heading "Task". This evaluation explains the description of the exercise wholly. It talks about the quality of exercise and activity, technique in activity, quality of instruction in exercise and composition of individual, 
pair work and group work in activity. The exercise involves language skills and language content assessments. Here is the proportion of the assessment evaluation.

\section{Chart 4 Assessment}

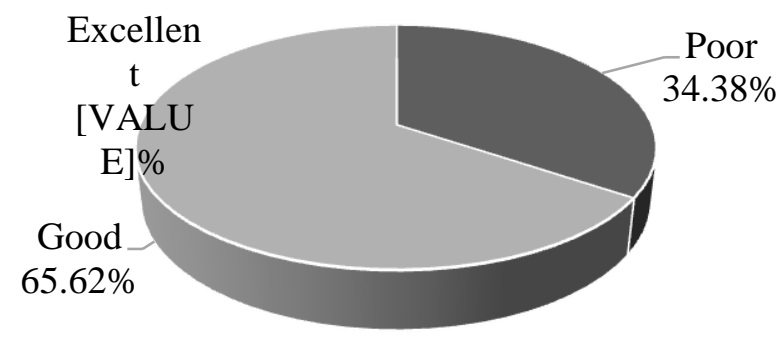

The pie chart illustrates that the students' worksheet obtains nearly two thirds of good in the term of assessment. The poor categorized item obtains only a third. While it doesn't obtain any excellent categorized at all. It shows that the quality of students' worksheet's assessment is merely good. Besides, there are some aspects that must be fixed due to develop the assessment, including the variety and the appropriateness to students' needs and ability.

\section{Assessment Synchronization}

The evaluation of synchronization between the exercises in the students' worksheet and learning objective in the syllabus is very important. It is because it will prove whether the exercise is referred to the syllabus or not. The fact researcher found is that even though the books are expensive, they are not always well designed. The exercises do not always synchronize to the curriculum and correspond with the objective of the teaching program and the needs of the students.

This research proves that, there are some exercises that do not synchronize with the syllabus. Some are because the materials and activities do not synchronize with the syllabus at the first place. It affects the exercises as well. The exercises mostly out from the rules. This causes bad effects, if the inappropriate exercises are done; it wastes the time to learn the important material that should be learned as their requirements. Therefore, it is very important to analyze whether the exercise fulfills the requirement or not. If it does not, then it will be stepped aside and do the required exercises instead.

\section{Chart 5 Assessment Synchronization}

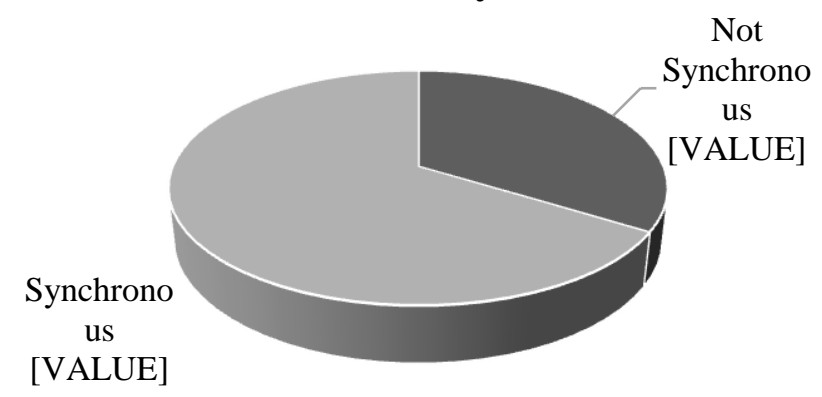

The pie chart illustrates that the students' worksheet's assessment synchronization is nearly two third of assessments portion. The not synchronous assessment loads a third of assessments portion. It indicates that the quality of students' worksheet's content is hesitated. Again, it is proven that the writer or the editor did not 
pay attention on the students of vocational schools' needs in the syllabus. Therefore, it is highly recommended that the arrangement of the students' worksheet or any other textbooks is based on the syllabus requirement.

\section{DISCUSSION}

From number of items in general appearance, the finding only points out some poor and most important items to be described specifically. The first item, is the quality of the picture. The quality of the pictures is influenced by the quality of layout, visual, and printing. Pictures are needed in reliving students' imagination and creativity in learning. The quality of the pictures determines the quality of the imagination and creativity that will appear after looking at the picture. Besides, it will trigger their motivation to learn more.

This students' worksheet provides only few pictures. It is only provided in the Learning Motivation (the preparation narration for entering core material), some selected language skill material, and some selected exercise. Moreover, the quality of the picture is not good. It uses black and white printing. Some pictures look blurred and not clear. The size is also small and not appropriate. Therefore, the situation of the students' worksheet is not life-like. It looks flat and not interesting. The additional pictures must be included in students' worksheet to make students motivated to learn and stimulate them to be more creative.

The next one is mistakes evaluation. This is the basic evaluation that is recommended to be done. Sometimes, the author of the book or students' worksheet doesn't have competence in arranging book or maybe they just do mistypes. It also happens to the editor, they either incompetent or didn't carefully check the book or students' worksheet. As a result, the mistakes happen in almost everywhere. This will make the students follow the mistakes without teacher's guidance.

This students' worksheet is not free of mistakes. There are some mistakes in the form of mistypes and grammatical errors. The total number of mistakes is 28 spread in different pages. The mistakes often happen in grammatical errors. They are found in main material, language skill passages, questions in task and exercise, and even in the glossary. The arrangement of the sentence seems done carelessly. It can lead students to generalization of error rules if the teacher doesn't correct it. Therefore such mistakes in the form of mistypes and grammatical errors must be avoided.

The last aspect is direction or guidance. The direction meant here is the guidance of using the book. This is very important in showing how the book or students' worksheet is organized and used in learning. The quality of direction and guidance has to be evaluated because there are some books and students' worksheets which gives the guidance in careless way. The evaluation is needed to reveal this carelessness and give the suggestion to develop books' quality.

There is a guidance of using this students' worksheet in the second page. It shows the concept map entitled "Pedoman Penggunaan Buku". It provides the view of some headings in the students' worksheet in the form of picture and description. In fact, the direction is clear and guide very well. Unfortunately, it gives the example of other subject's students' worksheet (Cultural Art) and uses Bahasa Indonesia. Besides the picture is blurred and the font size of description is too small, so it is unreadable. Below is the proportion of profile evaluation. 


\section{CONCLUSION AND SUGGESTION}

To sum up, there are many things that must be developed in order this students' worksheet can be beneficial and meaningful in English learning. The good thing in this students' worksheet is the effort to develop the four language skills in an integrated way in the units. It is done by trying to involve every skill in every unit and the receptive skills activities are used as input for the productive skills activities. However, each skill's tasks are not integrated all four skills. There are many flaws in every aspect that must be fixed due to develop the quality of this students' worksheet. The better quality of English students' worksheet determines the better quality of English learning process.

There are many things to be considered in arranging and developing learning sources in a printed book. For instance, whether the book has been synchronized to the curriculum, students' need and use appropriate language, etc. There are few things to be done in optimizing and developing this students' worksheet. Some of them is to make this students' worksheet synchronize to the applied curriculum. This is suggested because the fact that found is some contents and the assessment in this students' worksheet are out of the guidance in the syllabus. It also suggested that the students' worksheet contain fun and interesting element in the term of content, assessment, and layout to trigger students to be more creative.

Another suggestion is for the future researcher who wants to conduct studies on the topic of textbook or students' worksheet evaluation. Researchers must be selective in adopting and improvising criteria of evaluation. The evaluation items must be appropriate to the analyzed textbook and students' worksheet. It is also suggested the students' worksheet's publisher to revise the students' worksheet due to be more interesting, varied and synchronize to the curriculum's requirements and students' needs.

\section{REFERENCES}

Anjaneyulu, Thotapally. (2014). A Critical Analysis of the English Language Textbooks in Andhra Pradesh, India. International Association of Research in Foreign Language Education and Applied Linguistics, 181-200.

Bitterlin, Gretchen (2003) TESOL Standards for Adult Education ESL Programs. TESOL: Alexandria, Virginia

Brown, H. Douglass. (2003). Language Assessment Principle and Classroom Practices. California: Longman.

Cunningsworth, A (1995). Choosing your Textbook. London: Macmillan: Heinemann.

Demir, Y., \& Ertas, A. (2014). A Suggested Eclectic Checklist for ELT Coursebook Evaluation. The Reading Matrix, 243-252.

Departemen Pendidikan Nasional. (2004). Pedoman Umum Pengembangan Bahan Ajar Sekolah Menengah Atas. Departemen Pendidikan Nasional, Direktorat Pendidikan Menengah Umum.

Fitriyani, M. (2013). A Textbook Analysis of "When English Rings the Bell" A Textbook for the Seventh Grade of Junior High School. Unpublished Thesis. Yogyakarta: State University of Yogyakarta. 
Fredriksson, C., \& Olsson, R. (2006). English Textbook Evaluation: An Investigation into Criteria for Selecting English Textbooks. Malmö högskola, 1-35.

Kirana, A. M. (2010). Questioning Strategies Employed By Biology Teacher in RSBI Program at SMPN 5 Malang. Unpublished Thesis. Malang: State University of Malang.

Lawrence, W. P. (2011). Textbook Evaluation: A Framework for Evaluating The Fitness of The Hong Kong New Secondary School (NSS) CURRICULUM. Hong Kong.

Madjid, A. (2007). Perencanaan Pembelajaran (Mengembangkan Standar Kompetensi Guru). Bandung: PT. Remaja Rodakarya

Mulyasa, E. (2010). Kurikulum Tingkat Satuan Pendidikan. Bandung: Remaja Rosdakarya.

Neagley, R. L and Evans, N. D. (1967). Handbook for Effective Curriculum Development. Engleywood Cliffs. New Jersey: Prentice-Hall, Inc.

O’Neill, R. (1982). “Why use textbooks?” ELT Journal Vol. 36/2, Oxford University Press.

Tomlinson, B. (Ed.). (2003). Developing Materials for Language Teaching. London: Continuum.

Trianto. (2007). Model-model Pembelajaran Inovatif Berorientasi Konstruktivistik. Jakarta: Prestasi Pustaka

Wahab, D. M. (2013). Developing an English Language Textbook Evaluative Checklist. IOSR Journal of Research \& Method in Education (IOSR-JRME), 55-70.

Weddel, K. S. (2009). How to Choose a Good ESL Textbook. Northern Colorado Professional Development Center, 1-14. 